\title{
Kajian Kualitas Pelayanan Menuju Peningkatan Kepuasan Pelanggan Eksternal Fakultas Pertanian Universitas Mataram
}

\section{Assessment Of Service Quality Towards Increasing External Customer Satisfaction Faculty Of Agriculture Mataram University}

\author{
Tajidan*, Anwar, Hery Haryanto, Bambang Dipokusumo \\ Program Studi Agribisnis, Fakultas Pertanian, Universitas Mataram. \\ *Corresponding Author Email: m.tajidan@ gmail.com
}

Manuscript received: 08-12-2020. Accepted: 26-10-2021

\begin{abstract}
ABSTRAK
Tujuan penelitian ini adalah mengukur kualitas pelayanan unit pelaksana institusi perguruan tinggi, mengukur capaian tingkat kepuasan pelanggan eksternal, dan menganalisis keterkaitan antara kualitas pelayanan dengan tingkat kepuasan pelanggan eksternal. Untuk mencapai tujuan tersebut dilaksanakan penelitian dengan mengkombinasikan metode observasi, penyebaran angket kepada 200 orang pelanggan eksternal, diskusi kelompok terarah, dan konsultasi publik. Sebagai unit analisis dalam penelitian ini adalah pelanggan eksternal yang terdiri atas orang tua mahasiswa, alumni, pengguna lulusan, dan mitra kerjasama. Data yang terkumpul dianalisis menggunakan analisis statistik deskriptif, dan analisis statistik non parametrik yaitu korelasi rank spearman. Hasil penelitian menunjukkan: kualitas pelayanan unit pelaksana perguruan tinggi identik dengan tingkat kepuasan pelanggan eksternal; capaian tingkat kepuasan pelanggan eksternal adalah dari baik menuju sangat baik; kepuasan pelanggan eksternal alumni dan pengguna lulusan pada posisi baik, sementara pelanggan eksternal orang tua mahasiswa dan mitra kerjasama pada posisi sangat baik.
\end{abstract}

Kata kunci: alumni; mahasiswa; mitra Kerjasama; orang tua; pengguna lulusan

\begin{abstract}
The purpose of this study was to measure the service quality of the implementing unit of higher education institutions, to measure the level of external customer satisfaction, and to analyze the relationship between service quality and external customer satisfaction levels. To achieve these objectives, research was carried out by combining observation methods, distributing questionnaires to 200 external customers, focus group discussions, and public consultations. As the unit of analysis in this study, external customers consist of parents of students, alumni, graduate users, and cooperation partners. The collected data were analyzed using descriptive statistical analysis, and non-parametric statistical analysis, namely Spearman rank correlation. The results showed: the service quality of higher education implementing units is identical to the level of satisfaction of external customers; achievement of the level of external customer satisfaction is from good to very good; external
\end{abstract}


customer satisfaction of alumni and graduate users is in a good position, while external customers of students' parents and cooperation partners are in a very good position.

Keywords: alumni; students; cooperation partners; parents; graduate users

\section{PENDAHULUAN}

Isu strategis yang kini hangat didiskusikan adalah gagasan merdeka belajar bagi pendidikan dasar dan menengah dan kampus merdeka bagi perguruan tinggi. Belakangan isu tersebut digabungkan menjadi merdeka belajar kampus merdeka (MBKM). Isu strategis tersebut sebagian telah dituangkan dalam bentuk kebijakan atau Peraturan Menteri Pendidikan dan Kebudayaan, diantaranya yaitu Permendikbud Nomor 05 Tahun 2020 tentang Akreditasi Program Studi dan Perguruan Tinggi. Dalam Permendikbud tersebut Program Studi dan Perguruan Tinggi mendapat kemudahan dalam akreditasi. Peninjauan akreditasi yang sebelumnya bersifat wajib dan rutin setiap 5 (lima) tahunan, diubah menjadi akreditasi bersifat sukarela dan otomatis diperpanjang apabila telah berakhir periode berlakukan, kecuali ada pengaduan dari masyarakat, peminatnya menurun, dan lulusannya kurang diterima bekerja di pasar kerja. Perpanjangan akreditasi menggunakan pertimbangan data yang ada di Kementerian Pendidikan dan Kebudayaan. Reakreditasi diberikan kesempatan bagi Program Studi dan Perguruan Tinggi yang membutuhkan peningkatan status akreditasi yaitu dari Baik menjadi Baik Sekali, atau dari Baik Sekali menjadi Unggul. Sementara bagi Program Studi dan/atau Perguruan Tinggi yang telah terakreditasi internasional, maka secara otomatis memperoleh status akreditasi Unggul.

Kebijakan Mendikbud pada aspek akreditasi sebagaimana disebutkan di atas tampaknya mudah, namun sesungguhnya mengandung konsekuensi bahwa perguruan tinggi bertanggung jawab dalam memberikan pelayanan yang mampu meningkatkan kepuasan optimal kepada masyarakat khususnya kepada para pelanggan internal dan pelanggan eksternal. Capaian kepuasan pelanggan internal (mahasiswa, dosen, dan pegawai) dan pelanggan eksternal (orang tua mahasiswa, alumni, pengguna lulusan, dan mitra kerjasama) merupakan kunci keberlanjutan capaian akreditasinya. Capaian kepuasan pelanggan sebagai wujud pertanggungjawaban perguruan tinggi kepada publik bahwa perguruan tinggi memberi manfaat positif bagi masyarakat (Dirjen Pendidikan Tinggi, 2006). Lebih lanjut Suheri, et al. (2016) menggagas bahwa konsekuensi atas kebijakan tersebut adalah Unit Pengelola Program Studi dan Lembaga Pendidikan Tinggi agar menjaga dan meningkatkan mutu pendidikannya melalui penerapan Sistem Penjaminan Mutu Internal (SPMI).

Penerapan SPMI adalah upaya sadar dan terprogram untuk meningkatkan kualitas pelayanan secara berkelanjutan melalui pembentukan dan pengembangan budaya mutu (Anonymous, 2013b). Pengembangan budaya mutu yang diawali dengan komitmen penjaminan mutu dan ditindaklanjutkan dengan penerapan manajemen mutu yang meliputi Penetapan, Pelaksanaan, Evaluasi, Pengendalian, dan Peningkatan (PPEPP) Standar Nasional Pendidikan Tinggi. Ikhtiar pelaksanaan dari SPMI akan membuahkan mutu pelayanan yang semakin baik yang pada gilirannya meningkatkan kepuasan pelanggan.

Peningkatan kepuasan pelanggan dimungkinkan tercapai jika standar pelayanan yang dimiliki semakin baik (benchmarking) yang meliputi aspek input, process, output dan 
outcome (Anonymous, 2007a). Oleh karena itu peningkatan kualitas pelayanan menjadi pintu masuk bagi peningkatan kepuasan para pemangku kepentingan khususnya para pemangku kepentingan eksternal perguruan tinggi.

Berbagai hasil studi yang terkait dengan peningkatan kepuasan pelanggan atau konsumen memiliki korelasional dengan mutu atau kualitas pelayanan. Wardani (2017) dari hasil penelitiannya menunjukkan bahwa kualitas pelayanan memiliki keterkaitan dengan tingkat kepuasan pelanggan. Kualitas pelayanan yang diukur menggunakan reliability berpengaruh positif dan signifikan terhadap kepuasan pelanggan. Sedangkan hasil penelitian Sari (2015) mengindikasikan bahwa jaminan kualitas yang dapat dibuktikan langsung oleh pelanggan menjadi faktor penentu kepuasan konsumen atas pelayanan resto.

Kepuasan pelanggan ditentukan oleh banyak faktor sebagaimana dilaporkan oleh Panjaitan (2016). Faktor yang menentukan tingkat kepuasan adalah kehandalan, kepastian, kenyataan dan empati. Dari variabel independen tersebut, variabel empati yang paling berpengaruh. Dengan kata lain, pelayanan sepenuh hati menjadi kunci tercapainya tingkat kepuasan yang tinggi.

Capaian kepuasan pelanggan atau konsumen merupakan keterpaduan dari aspek tangible, reliability, responsibility, assurance, dan emphaty yang mana secara terintegrasi bahwa variabel independen tersebut berpengaruh terhadap capaian tingkat kepuasan pelanggan (Nilasari dan Istiatin, 2015). Interaksi antar variabel independen menghasilkan tingkat kepuasan secara bersama-sama. Hasil analisis lebih lanjut menunjukkan bahwa variabel empathy menunjukkan pengaruh yang signifikan. Sikap dan tindakan senyum, salam, sapa, dan service (4'S) menjadi penentu kepuasan pelanggan. Pelayanan yang cepat tanpa antri merupakan faktor pelayanan yang mudah dan murah, serta perolehan outcome (benefit/manfaat) bagi pelanggan memberikan efek positif bagi tercapainya tingkat kepuasan yang tinggi.

Hasil studi sebagaimana disebutkan di atas memberikan pelajaran berharga bagi lembaga pendidikan tinggi bahwa capaian tingkat kepuasan pelanggan ditentukan oleh kualitas pelayanannya. Pendidikan Tinggi merupakan industri jasa yang melayani pelanggan untuk mencapai peningkatan kualitas sumberdaya manusia (Tajidan, et al., 2016). Capaian kualitas sumberdaya manusia merupakan modal sosial untuk mencapai tingkat kesejahteraan yang lebih tinggi (Anonymous, 2007b). Hasil penelitian yang dilakukan oleh Sukartono, et al (2017) menunjukkan adanya peningkatan kepuasan pelanggan internal yang terdiri atas mahasiswa, dosen, dan pegawai dibandingkan dengan kepuasan tahun sebelumnya, namun bagaimana tingkat kepuasan pelanggan eksternal yang terdiri atas orang tua mahasiswa, alumni, pengguna lulusan, dan mitra kerjasama belum dilaksanakan, sehingga belum diketahui capaian tingkat kepuasannya. Sementara evaluasi tingkat kepuasan publik tersebut sangat berguna sebagai bahan pengambilan keputusan dan menentukan jenis pelayanan yang mesti ditingkatkan mutunya agar dicapai tingkat kepuasan yang maksimal (Halil, et al., 2015; Sehuri, et al., 2016). 


\section{Perumusan Masalah}

Capaian kepuasan pelanggan internal yang meningkat dari baik menuju sangat baik (Sukartono, et al., 2017) semestinya diikuti oleh semakin meningkatnya kepuasan pelanggan eksternal. Tingkat kepuasan pelanggan eksternal bukan semata ditentukan oleh kuantitas lulusan, melainkan ditentukan oleh interaksi antara kualitas lulusan dengan tantangan pekerjaan, tugas dan karir para alumni di masyarakat, selain itu seberapa cepat mereka memperoleh pekerjaan, jumlah take home pay yang mereka terima ketika pertama kali bekerja, dan kesesuaian bidang pekerjaan dengan bidang keahliannya (Suyanto, 2012; Tajidan, et al., 2016). Bagi para pengguna lulusan, tingkat kepuasan ditentukan oleh kemampuan para alumni dalam melaksanakan tugas, serta kemampuan mereka memecahkan permasalahan yang mereka hadapi, serta sejauh mana para alumni dalam memberikan manfaat bagi instansi/perusahaan di mana para alumni bekerja dan meniti karier (Sukartono, et al., 2017).

Sebagai lembaga pelayanan jasa pendidikan tinggi bidang pertanian, Fakultas Pertanian dituntut untuk terus menerus berinovasi, yaitu memberikan pilihan-pilihan yang mampu meningkatkan kepuasan pelanggan (customer satisfaction) eksternal (Sukartono, et al, 2017). Para dosen dan karyawan di Fakultas Pertanian hendak membangun branding atau benchmarking yang memiliki daya tarik bagi para pemangku eksternal, serta menghasilkan nilai bagi pelanggan, sehingga pada gilirannya para pelanggan eksternal mencapai tingkat kepuasan yang sesuai dengan harapannya.

Dalam era industri 4.0 dewasa ini dengan domain pelayanan berbasis internet telah memberikan kemudahan bagi para pemangku kepentingan. Membangun sistem informasi manajemen yang berbasis web telah menjadi kebutuhan, karena mendukung program go green dan paperless. Pelayanan publik yang berbasis web telah menjadi keniscayaan yang mau tidak mau harus diinternalisasi dalam setiap subsistem pendidikan tinggi agar dapat menjangkau pelanggan yang lebih luas, lebih beragam, serta mampu memberikan pelayanan non stop atau on time sepanjang waktu (one stop service).

Seiring dengan perkembangan teknologi, maka selera masyarakat pun berubah. Perubahan selera mengarah kepada produk yang makin berkualitas, pelayanan yang semakin lengkap dan sempurna, penggunaan yang makin mudah, praktis, fleksibel, serta harga yang bersaing. Oleh karena itu, para pelaku pelayanan jasa harus memahami atribut selera pelanggan. Attribut selera para pelanggan sebagai instrumen penting penetapan kebijakan peningkatan kualitas pelayanan, sementara atribut tersebut berubah terus menerus dari waktu ke waktu, sehingga perlu diperbaharui (up-dating) secara berkala.

\section{Tujuan}

Atas dasar rasionalisasi sebagaimana diuraikan di atas, maka dinilai penting untuk dilakukan Kajian Kepuasan Pelanggan Eksternal Fakultas Pertanian Universitas Mataram yang bertujuan: mengukur kualitas pelayanan unit pelaksana institusi perguruan tinggi, mengukur capaian tingkat kepuasan pelanggan eksternal, dan menganalisis keterkaitan antara kualitas pelayanan dengan tingkat kepuasan pelanggan eksternal. 


\section{Pengumpulan Data}

\section{METODE}

Data dan informasi dikumpulkan melalui gabungan beberapa teknik sebagai berikut:

a. Data kualitas pelayanan diperoleh dengan menggunakan metode penelaahan pustaka (desk study).

b. Data tingkat kepuasan pelanggan dilakukan dengan teknik penyebaran angket dalam format google.form. Sebagai objek angket adalah orang tua mahasiswa, alumni, pengguna lulusan, dan pimpinan mitra kerjasama. Angket dikirim melalui e-mail dan media sosial whatsApp.

\section{Analisis Data}

a. Untuk mencapai tujuan mengukur kualitas pelayanan dianalisis menggunakan analisis isi.

b. Untuk mengukur capaian tingkat kepuasan pelanggan dilakukan analisis menggunakan deskriptif persentase yang ditampilkan dalam format tabel.

c. Untuk mengetahui posisi kepuasan pelanggan eksternal menggunakan pembobotan tingkat kepuasan pelanggan, yaitu bobot $=1$ apabila tingkat kepuasan kurang, bobot=2 apabila tingkat kepuasan cukup, bobot=3 apabila tingkat kepuasan baik, dan bobot=4 apabila tingkat kepuasan sangat baik, selanjutnya dihitung nilai jumlah bobot dikali persentase capaian tingkat kepuasan pelanggan eksternal, selanjutnya diklasifikasikan sebagai berikut:

$\begin{array}{llc}\text { Kurang } & : & <175 \\ \text { Cukup } & : & 175-249 \\ \text { Baik } & : & 250-324 \\ \text { Sangat Baik } & : & >325\end{array}$

\section{HASIL DAN PEMBAHASAN}

\section{Kualitas Pelayanan Unit Pelaksana Institusi Perguruan Tinggi}

Kualitas pelayanan diukur dari kesesuaian antara harapan pelanggan dengan pelayanan yang diberikan. Semakin dekat jarak antara harapan pelanggan dengan pelayanan yang disediakan, maka semakin tinggi kualitas pelayanan. Ratih (2020) melakukan pendekatan bahwa kualitas pelayanan dikatakan sangat baik apabila sesuai dengan keinginan pelanggan, yaitu jika pelanggan merasa puas dengan produk serta pelayanan institusi, maka kualitas pelayanan dikatakan baik. Apabila pelayanan yang diberikan melebihi harapan pelanggan, maka dikatakan kualitas pelayanan sangat baik atau sangat memuaskan identik dengan kualitas pelayanan sangat baik. Kualitas pelayanan yang buruk adalah apabila pelayanan yang diterima tidak sesuai dengan harapan pelanggan atau institusi tidak memenuhi keinginan pelanggan. Pelayanan di bawah standar disebut kualitas pelayanan buruk.

Kualitas pelayanan yang baik harus dipertahankan atau ditingkatkan menjadi sangat baik oleh institusi melalui peningkatan kualitas sumberdaya manusia, yaitu melalui proses pendidikan dan pelatihan secara berkelanjutan dengan materi dan metode pelatihan yang sesuai dengan tuntutan kebutuhan pelanggan. 


\section{Tingkat Kepuasan Pelanggan Eksternal}

1. Orang Tua Mahasiswa

Atribut yang digunakan Orang Tua Mahasiswa dalam mengukur tingkat kepuasannya sebagai berikut:

a. Besarnya biaya yang dikeluarkan yang diukur dari jumlah Uang Kuliah Tunggal (UKT) yang mereka bayar, semakin rendah jumlah uang kuliah tunggal yang mereka bayar, maka semakin tinggi tingkat kepuasannya;

b. Indek prestasi komulatif (IPK) yang dicapai oleh anak mereka ketika kuliah;

c. Lama studi, semakin cepat selesai semakin tinggi tingkat kepuasannya;

d. Waktu tunggu bagi anaknya memperoleh pekerjaan yang layak setelah mereka wisuda;

e. Rentang/level wilayah kerja pada perusahaan / institusi tempat anaknya bekerja (lokal, nasional, dan internasional);

f. Besarnya penghasilan yang diperoleh saat pertama kali bekerja.

Dari keenam atribut tersebut diantaranya yang dipilih oleh orang tua mahasiswa adalah besarnya Uang Kuliah Tunggal (UKT), Indek Prestasi Kumulatif (IPK) dan lama studi dengan harapan memperoleh manfaat meningkatkan pengetahuan atau keahlian bidang pertanian. Atribut dan Tingkat kepuasan yang dicapai oleh orang tua mahasiswa sebagaimana tercatat pada Tabel 1 .

Tabel 1. Capaian Tingkat Kepuasan Orang Tua Mahasiswa Pada Tiap Atribut

\begin{tabular}{lrrrc}
\hline \multicolumn{1}{c}{ Atribut } & \multicolumn{4}{c}{ Kepuasan Orang Tua Mahasiswa (\%) } \\
& Kurang & Cukup & Baik & Sangat Baik \\
\hline 1. Besar UKT & - & 12.12 & 48.48 & 39.39 \\
2. Indek Prestasi Akademik & - & 1.89 & 81.13 & 16.98 \\
3. Waktu Penyelesaian Studi & 3.3 & 9.09 & 27.27 & 60.61 \\
Rata-rata & 1.01 & 7.70 & 52.30 & 38.99 \\
\hline
\end{tabular}

Capaian tingkat kepuasan orang tua dari baik menuju sangat baik. Deskripsi pada Tabel 1 memperlihatkan bahwa $52.30 \%$ dari jumlah responden orang tua dengan capaian tingkat kepuasan baik dan $38.99 \%$ dengan capaian tingkat kepuasan sangat baik. Sementara capaian tingkat kepuasan tertinggi diperoleh pada atribut waktu penyelesaian studi yaitu $60.61 \%$ menyatakan sangat puas. Hal ini didukung oleh rata-rata waktu studi 9 semester dari 14 semester yang diperbolehkan, artinya semakin singkat waktu penyelesaian studi maka semakin tinggi capaian kepuasan orang tua mahasiswa. Yang terbaik kedua adalah besar Uang Kuliah Tunggal yang mesti mereka bayar. Dari 23 orang responden orang tua mahasiswa terdapat 39,39\% menyatakan sangat baik.

Atribut kepuasan pelanggan sejalan dengan apa yang dikemukakan oleh Riadi (2013) yaitu tolok ukur tingkat kepuasan ditentukan oleh banyak faktor. Selain jenis layanan yang tersedia, juga yang menjadi pertimbangannya adalah harga, kualitas, tersedianya garansi (layanan purna jual), penataan dan kenyamanan ruang, kualitas produk, dan banyak lagi lainnya, serta disarankannya bahwa dalam praktik tercapainya kepuasan pelanggan tidak 
cukup dengan tercapainya kepuasan pribadi konsumen yang bersangkutan, melainkan juga memperhatikan beberapa hal sebagai berikut:

a. Pelanggan adalah tamu yang mesti dilayani dengan baik, karena ia dipandang sebagai orang penting;

b. Pelanggan adalah subyek mendatangkan keuntungan finansial;

c. Pelanggan bukan pihak yang diajak untuk berdebat, melainkan mendengarkan keluhan dan dipenuhi harapannya, karena itu kebutuhannya dipenuhi sebagaimana mestinya dalam hubungan berbisnis;

d. Pelanggan perlu didengarkan dan diperhatikan, karena ia juga manusia biasa yang memiliki perasaan suka, benci, duka, dan senang;

e. Setiap pelanggan ingin dilayani terlebih dahulu, karena itu perlu diupayakan pelanggan tidak menunggu lama, namun secepatnya disapa, dan dipenuhi keinginannya.

\section{Alumni}

Seluruh Alumni Fakultas Pertanian Universitas Mataram tergabung dalam Organisasi Ikatan Keluarga Alumni Fakultas Pertanian dan Ikatan Keluarga Alumni Universitas Mataram. Para alumni memiliki ikatan emosional dan masih tetap memerlukan almamaternya dan almamater memerlukannya untuk mendukung kemajuan institusi pendidikan tinggi. Pada para alumni diharapkan dapat membantu juniornya dalam mendapatkan pekerjaan dan memberikan kontribusi bagi penyediaan sarana dan prasarana pendidikan dan sarana prasarana penunjang pendidikan, serta institusi menyediakan berbagai layanan kepada alumni diantaranya adalah legalisasi transkrip nilai, legalisasi ijazah, dan pendampingan organisasi ikatan keluarga alumni. Layanan institusi Fakultas Pertanian digunakan sebagai atribut dalam menentukan tingkat kepuasan mereka sebagaimana disajikan pada Tabel 2.

Tabel 2. Capaian Tingkat Kepuasan Alumni Pada Tiap-tiap Atribut

\begin{tabular}{lrrrc}
\hline \multirow{2}{*}{ Atribut } & \multicolumn{4}{c}{ Capaian Tingkat Kepuasan Alumni (\%) } \\
& Kurang & Cukup & Baik & Sangat Baik \\
\hline 1. Legalisasi Transkrip Nilai & 4.35 & 21.74 & 43.48 & 30.43 \\
2. Legalisasi Ijazah & 8.70 & 13.04 & 52.17 & 26.09 \\
3. Pendampingan Organisasi IKA & 0.00 & 8.70 & 65.22 & 26.09 \\
Rata-rata & 4.35 & 14.49 & 53.62 & 27.54 \\
\hline
\end{tabular}

Rata-rata tingkat capaian kepuasan alumni masuk dalam kategori baik menuju sangat baik. Persentase capaian tingkat kepuasan terbanyak ada pada tingkat baik disusul oleh sangat baik, cukup dan kurang.

Capaian tingkat kepuasan alumni per atribut memperlihatkan bahwa capaian tingkat kepuasan yang kurang dijumpai pada atribut legalisasi ijazah dan legalisir transkrip, bagi alumni yang capaiannya kurang diduga disebabkan oleh pelayanan yang lambat, yang belum bisa selesai dalam waktu satu hari disebabkan karena pejabat dekan atau wakil dekan bidang akademik yang sedang tidak ada di tempat. Secara umum layanan legalisir transkrip dan layanan legalisasi ijazah dapat rampung dalam satu hari, namun dalam kenyataannya bisa 
lebih dari satu hari bahkan bisa satu minggu. Keterlambatan dalam layanan mengakibatkan alumni merasa kecewa, selain itu karena mereka dikenakan biaya legalisasi yang besarnya Rp10,000 per lembar. Ke depan diharapkan pembebanan biaya legalisasi transkrip dan legalisasi ijazah sedapat mungkin ditiadakan agar dan dipercepat prosesnya penyelesaiannya dari one day service menjadi just minute service.

Dalam upaya mewujudkan harapan di atas, perlu diperhatikan pula tipe kepuasan pelanggan dan ketidakpuasan pelanggan sebagaimana telah diuraikan ulang oleh Fikri, et al., 2016) yang dikutip dari Tjiptono (2005) sebagai berikut:

a. Tipe kepuasan aktif yaitu adanya emosi positif dari pelanggan berupa optimisme dan kepercayaan;

b. Tipe kepuasan stabil yaitu pelanggan yang menghendaki penyediaan jasa yang tetap sama;

c. Tipe kepuasan memaklumi yaitu merasa puas karena tidak berharap akan memperoleh lebih baik atau lebih banyak, sehingga apa yang dirasakannya dianggap sudah cukup memadai.

d. Tipe ketidakpuasan yang stabil adalah apa yang diharapkan belum memuaskannya, namun tidak berupaya untuk mendapatkan kepuasan yang lebih tinggi;

e. Tipe ketidakpuasan aktif adalah perilaku menuntut atau komplain dengan melakukan protes atau memberikan saran bagi perbaikan kedepannya.

f. Ciri pelanggan yang puas adalah (Kotler, 2003; Fikri et al., 2016):

g. Menjadi pelanggan yang loyal.

h. Meningkatkan volume pelayanan.

i. Memberi komentar positif.

j. Kurang memperhatikan / kurang tertarik terhadap layanan produk.

k. Kurang sensitif pada harga

1. Memberikan gagasan kepada para pelayan

m. Meminta pelayanan dengan biaya yang lebih murah.

3. Pengguna Lulusan

Pengguna lulusan adalah dinas / instansi pemerintah dan perusahaan-perusahaan yang bergerak bidang agribisnis dalam arti luas meliputi Dinas Pertanian dan Perkebunan Provinsi, Dinas Pertanian Kabupaten / Kota, Lembaga Keuangan Perbankan, dan perusahaan yang bergerak di bidang pertanian dan bidang bukan pertanian. Dalam kajian ini yang dipilih adalah Dinas/Instansi, Sekolah dan/atau perusahaan di mana alumni bekerja, diantaranya adalah Dinas Ketahanan Pangan dan Pertanian Kabupaten Lombok Utara, Unit Pelaksana Teknis Dinas Ketahanan Pangan dan Pertanian Kecamatan Tanjung, Balai Penyuluh Pertanian Kecamatan Sikur Lombok Timur, SMK Darul Jihad NW, PT Bisi International tbk, dll 
Tabel 3. Atribut dan Capaian Tingkat Kepuasan Pengguna Lulusan Fakultas Pertanian Universitas Mataram

\begin{tabular}{lrrrr}
\hline \multirow{2}{*}{ Atribut } & \multicolumn{3}{c}{ Capaian Tingkat Kepuasan Pengguna Lulusan (\%) } \\
& Cukup & \multicolumn{1}{c}{ Baik } & Sangat Baik \\
\hline 1. Loyalitas & - & 82.14 & 17.86 \\
2. Kejujuran & - & 75.00 & 25.00 \\
3. Kemandirian & 7.14 & 67.86 & 25.00 \\
4. Kemampuan Manajerial & 7.14 & 71.43 & 21.43 \\
Rata-rata & 3.57 & 74.11 & 22.32 \\
\hline
\end{tabular}

Sumber: Transform Data Primer

Atribut kepuasan pengguna lulusan yang digunakan adalah karakteristik lulusan yang terdiri atas loyalitas, kejujuran, kemandirian dalam memecahkan masalah dan bekerja, serta kemampuan manajerial. Sebagian besar pengguna lulusan memperoleh tingkat "baik" sebesar $74.11 \%$ dari 28 instansi / perusahaan pengguna lulusan, dan $22.32 \%$ "sangat baik" dari 28 orang responden, hanya sebagian kecil $(3.74 \%)$ dari jumlah responden pada level "cukup" pada atribut kemandirian dan manajerial.

Studi tingkat kepuasan pengguna lulusan tampaknya konsisten dengan hasil studi pelacakan (tracer study) lulusan tahun 2012 sampai dengan tahun 2015 bahwa para pengguna lulusan memberikan penilaian positif atas kinerja para alumni Fakultas Pertanian Universitas Mataram dari tingkat kepuasan baik menuju tingkat kepuasan sangat baik.

Sehubungan dengan hasil penelitian dan didukung oleh hasil penelitian lainnya bahwa kualitas pelayanan berkorelasi positif dengan tingkat kepuasan, maka ke depan diperlukan pelayanan prima (excellent service) untuk mencapai kepuasan sangat baik. Kaitan dengan dukungan hasil penelitian dengan mengutip pendapat Tjiptono (2016) bahwa kualitas pelayanan adalah upaya memenuhi kebutuhan dan ketepatan pelayanan yang sesuai dengan harapan pelanggan (konsumen). Kepuasan pelanggan ditentukan oleh tersedianya banyak pilihan atau banyaknya item pilihan, semakin banyak tersedia pilihan, maka konsumen dapat memaksimalkan pencapaian kepuasannya; sementara Suprapto cit. Riadi (2013) mendefinisikan kualitas pelayanan sebagai tindakan terbaik yang mesti dikerjakan dengan baik. Sementara menurut Ratminto cit. Riadi (2013) kualitas pelayanan dimaksudkan untuk memecahkan permasalahan pelanggan melalui interaksi antara karyawan dengan konsumen. Pelayanan merupakan usaha jasa di samping produk ditawarkan yang berorientasi pada kepuasan pelanggan.

Kualitas pelayanan dapat dibedakan menjadi dua kriteria, yaitu kualitas pelayanan yang baik dan kualitas pelayanan yang buruk. Kualitas pelayanan yang baik adalah pelayanan yang sesuai dengan harapan pelanggan atau memenuhi selera pelanggan. Kualitas pelayanan yang buruk adalah pelayanan yang memperlakukan pelanggan jauh dari harapanmu. Kualitas pelayanan cenderung bersifat universal artinya berlaku bagi semua orang, namun kualitas pelayanan dapat diubah atau diperbaiki dengan mengubah perilaku (conduct). Perbaikan kualitas pelayan dapat dilakukan dengan cara survey atau observasi kepada pelanggan, menginventarisasi dan menganalisis masukan, pendapat, atau feedback. Membandingkan 
pelayanan yang diterima dengan harapan pelanggan atas pelayanan yang diberikan menjadi atribut kualitas pelayanan. Semakin dekat harapan pelanggan dengan pelayanan yang diberikan menunjukkan semakin meningkatnya kualitas pelayanan, sebaliknya semakin senjang antara harapan dengan kenyataan, maka semakin rendah kualitas pelayanan (Anonim, 2016; Fikri, et al, 2016).

Kualitas pelayanan berdampak langsung terhadap citra lembaga pendidikan tinggi dalam pandangan publik. Kualitas pelayanan yang baik akan berdampak positif dan menguntungkan bagi lembaga pendidikan. Pelayanan yang baik menghasilkan respon yang baik bagi pelanggan, sehingga memungkinkan bagi mereka menjadi pelanggan tetap.

Hasil studi pelacakan alumni periode 2016 sampai dengan bulan Juli 2020 dengan menggunakan kategori tingkat kepuasan pengguna lulusan kurang, cukup, baik dan sangat baik sebagian besar mengemukakan bahwa para pengguna lulusan memperoleh kepuasan pada level "baik" (Tajidan, et al., 2020). Penelitian tersebut menggunakan atribut etika, keahlian bidang ilmu, kemampuan bahasa asing (English), penggunaan teknologi informasi, kemampuan komunikasi, kerjasama dalam tim, dan pengembangan diri. Analisis dengan menggunakan data transformasi persentase pada Program Studi Agribisnis dan Program Studi Agroekoteknologi menunjukkan kecenderungan pada level tingkat kepuasan "baik" sementara pengguna lulusan Program Studi Budidaya Perairan dan Program Studi Kehutanan yang mencapai level "sangat baik" .

Pengguna lulusan adalah pelanggan institusi pendidikan. Lulusan adalah produk perguruan tinggi yang mana konsumennya adalah dinas / instansi atau perusahaan yang menggunakan lulusan. Mengetahui tingkat kepuasan pengguna lulusan bermanfaat bagi perbaikan institusi pendidikan tinggi sebagaimana yang tertuang dalam Laporan Kinerja Program Studi yang diterbitkan oleh Badan Akreditasi Nasional Perguruan Tinggi (BANPT). Tingkat kepuasan yang dicapai oleh pengguna lulusan telah memberikan gambaran positif bagi institusi Fakultas Pertanian bahwa produk yang dihasilkannya mendapat apresiasi dari para atasannya masing-masing. Hasil kajian ini masih memiliki kelemahan dilihat dari jumlah respondennya yang relatif sedikit dibandingkan dengan jumlah alumni yang bekerja. Kelemahan di atas dicoba diatasi dengan mewawancarai pengguna lulusan untuk mengetahui atribut atau kualifikasi apa yang mereka butuhkan.

Tiap pengguna lulusan membutuhkan atribut yang bervariasi, namun secara umum atribut etika, kejujuran, loyalitas, kemandirian, kepemimpinan, kemampuan bahasa asing, serta kemampuan mengoperasikan komputer dan penggunaan teknologi informasi, selain kemampuan penguasaan bidang ilmu, juga kemudahan beradaptasi dengan lingkungan pekerjaan. Atribut atau kualifikasi lulusan yang dibutuhkan oleh para pengguna lulusan menjadi bahan kajian lebih lanjut, sehingga pendekatan yang dilakukan tidak menimbulkan gap atau instrumen kajian yang digunakan memiliki reliabilitas yang tinggi. Sementara penelitian yang dilakukan oleh Ira Setyaningsih dan Abrori (2012) yang menemukan adanya gap antara atribut yang diharapkan oleh pengguna lulusan dengan kualifikasi lulusan perguruan tinggi di Yogyakarta, sehingga pengguna tidak puas, diduga penyebabnya adalah kesalahan metodologi dengan menggunakan uji tanda atau maching. Realitas tingkat kepuasan yang berskala ordinal tidak tepat memandang atribut sebagai skala nominal, 
sehingga wajar hasilnya tidak sesuai dengan realitas bahwa pengguna lulusan membutuhkan lulusan perguruan tinggi melalui proses seleksi dan pembinaan.

\section{Mitra Kerjasama}

Fakultas Pertanian Universitas Mataram sebagai institusi / lembaga pendidikan tinggi memiliki produk layanan yaitu pendidikan, penelitian, dan pengabdian kepada masyarakat. Pendidikan atau pelatihan merupakan produk layanan untuk peningkatan kapasitas sumberdaya manusia (Capacity Building). Juga menyediakan produk berupa hasil kajian dalam rangka menghasilkan dokumen yang diperlukan sebagai dasar dalam pengambilan keputusan. Pembinaan masyarakat atau bentuk pengabdian lainnya juga dibutuhkan khususnya bagi penyaluran teknologi produksi dalam rangka peningkatan kesejahteraan masyarakat.

Fakultas Pertanian telah bekerjasama dengan beberapa Instansi / Dinas Pemerintah Daerah Provinsi dan Kabupaten, diantaranya adalah:

a. Dinas Pertanian dan Perkebunan Provinsi Nusa Tenggara Barat

b. Dinas Pertanian Kabupaten Lombok Timur

c. Badan Perencanaan Pembangunan Daerah Kabupaten Lombok Utara,

d. Badan Perencanaan Pembangunan Kabupaten Lombok Barat,

e. Dinas Lingkungan Pemukiman dan Perumahan Kabupaten Lombok Utara.

Atribut yang digunakan dalam menilai kualitas pelayanan Institusi Fakultas Pertanian Universitas Mataram dalam menjalin kerjasama sebagaimana tercantum pada Tabel 4

Tabel 4. Atribut Kepuasan Pelanggan Mitra Kerjasama

\begin{tabular}{clcc}
\hline \multirow{2}{*}{ No } & \multicolumn{1}{c}{ Atribut } & \multicolumn{3}{c}{ Capaian Kepuasan Pelanggan Mitra Kerjasama } \\
& \multicolumn{1}{c}{ Baik } & Sangat Baik \\
\hline 1 & $\begin{array}{l}\text { Kecepatan dalam merespon usulan } \\
\text { kerjasama }\end{array}$ & 60 & 40 \\
2 & $\begin{array}{l}\text { Kesesuaian dengan harapan / target / } \\
\text { sasaran }\end{array}$ & 80 & 20 \\
3 & $\begin{array}{l}\text { Ketepatan waktu, sasaran dan target } \\
\text { dalam penyelesaian pekerjaan }\end{array}$ & 60 & 40 \\
4 & $\begin{array}{l}\text { Luaran yang dihasilkan memberikan } \\
\text { manfaat bagi sasaran }\end{array}$ & 80 & 20 \\
5 & $\begin{array}{l}\text { Kesesuaian implementasi dan proses } \\
\text { dengan substansi kerjasama }\end{array}$ & 60 & 40 \\
6 & $\begin{array}{l}\text { Akuntabilitas pelaksanaan dan } \\
\text { pelaporan }\end{array}$ & 60 & 40 \\
\hline Rata-rata & 66.67 & 33.33 \\
\hline
\end{tabular}

Sumber: Data Primer

Ada tiga pilar pelayanan prima dalam rangka meningkatkan kepuasan pelanggan, yaitu (https://www.sonora.id/read/422319993/tiga-pilar-penting-terwujudnya-service-excellencedi-perusahaan-apa-saja?page=all): 
a. Produk

Perguruan Tinggi benar-benar memperhatikan produk atau jasa yang mereka tawarkan, yaitu produk atau jasa yang berkualitas atau bermutu. Kualitas dapat dilihat dari kualifikasi 6 (enam) atribut sebagaimana telah ditulis pada Tabel 4. Paket-paket pendidikan / pelatihan, penelitian, dan pengabdian hendaknya disediakan dan dipersiapkan dengan matang agar memenuhi atau melampaui harapan para pelanggan.

b. Proses

Produk atau jasa yang berkualitas akan bermakna bagi pelanggan apabila proses pelayanan sesuai atau melampaui harapan pelanggan. Kualitas produk atau jasa tidak akan berdampak positif bagi peningkatan kepuasan pelanggan apabila proses pelayanannya kurang baik. Oleh karena itu proses pelayanan hendaknya menjadi perhatian setelah produk atau jasa berkualitas yang dapat disediakan kepada pelanggan. Fakultas Pertanian Universitas Mataram hendaknya memiliki Standar Operasional Prosedur (SOP) yang terdokumentasi setiap jenis kerjasama yang ditawarkan kepada para pelanggan. Tersedianya SOP atau manual mutu merupakan komponen penting dalam Sistem Penjaminan Mutu Internal (SPMI) yang meliputi Penetapan, Pelaksanaan, Evaluasi, Pengendalian dan Peningkatan (PPEPP).

c. Sumberdaya Manusia

Produk, proses, dan sumberdaya manusia sebagai tiga pilar pelayanan prima yang merupakan satu kesatuan yang tak terpisahkan. Kualitas sumberdaya manusia yang berinteraksi dengan para pelanggan akan dapat mengubah situasi dan kondisi menjadi lebih baik. Produk dan proses yang berkualitas tergantung pada sumberdaya manusianya yang berkualitas. Sumberdaya manusia yang memiliki kecerdasan intelegensi, kecerdasan emosional,dan kecerdasan religiusitas. Kualifikasi sumberdaya manusia dapat dilihat dari jabatan fungsional, jenjang kepangkatan, dan kualifikasi pendidikan, serta track record (pengalamannya) dapat dinilai dari Daftar Riwayat Hidup (Curriculum Vitae). Kepakaran sumberdaya manusia dapat meyakinkan para pelanggan untuk membeli layanan produk atau jasa dan bersedia membayar lebih tinggi dari harga yang ditawarkan. Pada Tabel 4 bahwa tingkat kepuasan mitra kerjasama dari baik menuju sangat baik, setelah dianalisis bahwa tingkat kepuasan mitra kerjasama mencapai sangat baik.

Dari tiga pilar sebagaimana diuraikan di atas tampak bahwa Fakultas Pertanian Universitas Mataram memiliki kualifikasi sumberdaya manusia dan proses, sementara kualifikasi produk belum ada ukurannya, sebab spesifikasi produk yang dihasilkan dinilai sendiri oleh pihak pengguna eksternal. Kualitas produk inheren dengan kepuasan para pelanggan. Kualitas produk yang dihasilkan berupa dokumen atau informasi yang dihasilkan dan digunakan oleh pelanggan, hanya pelanggan yang dapat mengetahuinya. Oleh karena produk bersifat pesanan, spesifikasi produk diuraikan dalam proposal atau kerangka acuan kerja yang menjadi dasar kesepakatan kerjasama. Persetujuan atas kuantitas dan kualitas produk dalam proposal menjadi standar kualitas produk. Proses layanan telah tersedia Standar Operasional Prosedur (SOP) atau Prosedur Operasional Baku (POB) yang dapat digunakan sebagai pedoman dalam memberikan pelayanan. 
Untuk mengatasi kelemahan sebagaimana ditulis di atas serta solusi pemecahan masalah tersebut, maka dilakukan transformasi data dengan menggunakan pembobotan atas tiap level tingkat kepuasan dari 1 (satu) sampai dengan 4 (empat), sehingga diperoleh nilai jumlah bobot kali persentase sebagaimana hasil analisisnya tampak pada Tabel 5.

Tabel 5. Jumlah Nilai Bobot kali Persentase Tingkat Kepuasan Pelanggan Eksternal

\begin{tabular}{lcccrc}
\hline \multirow{2}{*}{ Pelanggan Eksternal } & \multicolumn{4}{c}{ Nilai Tingkat Kepuasan } & Jumlah (bobot \\
& Kurang & Cukup & Baik & Sangat Baik & x \%) \\
\hline Orang Tua Mahasiswa & 1.01 & 15.40 & 156.89 & 155.97 & 329.27 \\
Alumni & 4.35 & 28.99 & 160.87 & 110.14 & 304.35 \\
Pengguna Lulusan & & 7.14 & 222.32 & 89.29 & 318.75 \\
Mitra Kerjasama & & 0.00 & 200.01 & 133.32 & 333.33 \\
\hline
\end{tabular}

Kriteria Jumlah Nilai Bobot kali Persentase ditransformasi ke empat kelas sebagai berikut:

$\begin{array}{lcc}\text { Kurang } & : & <175 \\ \text { Cukup } & : & 175-249 \\ \text { Baik } & : & 250-324 \\ \text { Sangat Baik } & : & >325\end{array}$

Pada Tabel 5 tampak bahwa posisi tingkat kepuasan menggunakan kriteria sebagaimana disusun tersebut di atas. Mencocokkan (matching) antara kriteria dengan jumlah nilai bobot $\mathrm{x}$ persentase diketahui bahwa tingkat kepuasan mitra kerjasama dan orang tua mahasiswa tergolong "sangat baik" sementara kepuasan alumni dan pengguna lulusan tergolong "baik".

Banyak cara yang dapat dilakukan untuk meningkatkan kualitas pelayanan. Yang terpenting adalah melakukan evaluasi dan perbaikan. Evaluasi dilakukan secara periodik minimal sekali dalam satu tahun. Kajian kualitas pelayanan adalah cara memperoleh feedback untuk memperbaiki kualitas pelayanan. Cara yang tepat meningkatkan kualitas pelayanan adalah (Fikri, et al., 2016):

a. Mendapatkan umpan balik dari pelanggan yaitu dengan melakukan survey

b. Melakukan evaluasi pelayanan yaitu dengan mengumpulkan data-data yang terkait atas pelayanan yang dikeluhkan oleh para pelanggan. Pengungkapan keluhan adalah merupakan kritikan yang bersifat membangun bagi upaya peningkatan kualitas pelayanan.

c. Melakukan tindakan perbaikan pelayanan melalui proses pengarahan, pelatihan, dan pendidikan karyawan yang berhubungan langsung dengan pelanggan, memperbanyak akses, fasilitas, dan penyediaan panduan.

Tujuan pelayanan adalah agar konsumen merasakan tercapainya kepuasan (satisfaction) yang berdampak pada tercapainya keuntungan bagi institusi (Riadi, 2013; Fikri, et al., 2016)). Adapun dimensi kualitas pelayanan adalah:

a. Tangibles (bukti fisik) yaitu kemampuan dalam menunjukkan eksistensi diri kepada pihak eksternal; 
b. Reliability (kehandalan) yaitu mampu memberikan pelayanan sesuai dengan janjinya atau slogannya;

c. Responsiveness (ketanggapan) yaitu kemauan untuk membantu dan memberikan pelayanan yang cepat (responsif) dalam takaran yang tepat kepada pelanggan;

d. Assurance (jaminan dan kepastian) yaitu perilaku tata krama kesopanan yang menumbuhkan kepercayaan para pelanggan. Terdiri dari beberapa komponen, yaitu komunikasi, kredibilitas, keamanan, kompetensi, dan sopan santun / tata krama pergaulan);

e. Empathy (empati) yaitu memberikan perhatian dan pelayanan yang tulus ikhlas, atau pelayanan sepenuh hati.

\section{Kesimpulan}

\section{KESIMPULAN}

Kualitas pelayanan unit pelaksana perguruan tinggi identik dengan tingkat kepuasan pelanggan eksternal, Capaian tingkat kepuasan pelanggan eksternal adalah dari baik menuju sangat baik, dan kepuasan pelanggan eksternal alumni dan pengguna lulusan pada posisi baik, sementara pelanggan eksternal orang tua mahasiswa dan mitra kerjasama pada posisi sangat baik.

\section{Saran}

Dalam rangka meningkatkan kualitas pelayanan, perlu diterapkan 3 (tiga) pilar pelayanan yaitu kualitas produk, perbaikan proses dan peningkatan kapasitas sumberdaya manusia. Sedangkan dalam upaya meningkatkan kepuasan pelanggan eksternal, maka perlu diterapkan pelayanan prima (excellent service) dengan tindakan cepat mudah murah dan fleksibel; serta dalam mengimplementasikan pelayanan prima hendaknya melampaui harapan pelanggan agar dapat dicapai tingkat kepuasan sangat baik.Peningkatan kapasitas sumberdaya manusia dimungkinkan apabila dilaksanakan pelatihan pelayanan prima secara rutin dan berkala.

\section{Ucapan Terima Kasih}

Terima kasih disampaikan kepada Rektor dan Ketua Lembaga Penelitian dan Pengabdian Kepada Masyarakat, Dekan Fakultas Pertanian dan Ketua Badan Pengembagan Penelitan dan Pengabdian Kepada Masyarakat Fakultas Pertanian Universitas Mataram serta para pihak yang membantu terselenggaranya publikasi paper ini.

\section{DAFTAR PUSTAKA}

Anonymous. 2013a. Pengertian Kualitas Pelayanan. https://www.kajianpustaka.com Anonymous. 2013b. Manual Prosedur: Audit Mutu Internal. Universitas Sultan Ageng Tirtayasa. Bangkalan.

Anonymous. 2013c. Instrumen Audit Mutu Internal. Universitas Andalas. Padang. Anonymous. 2007a. Pedoman Audit Mutu Internal. Universitas Katolik Indonesia Atma Jaya. Jakarta. 
Anonymous. 2007b. Prosedur Mutu: Audit Mutu Internal. Universitas Negeri Semarang. Semarang.

BAN-PT. 2008. Pedoman Evaluasi Diri: Untuk Akreditasi Program Studi dan Institusi Perguruan Tinggi. Badan Akreditasi Nasional Perguruan Tinggi. Jakarta.

Basri, S. 2012. Uji Korelasi Spearman dengan SPSS dan Manual. Metode Penelitian. setabasri01.blogspot.com.

Dirjen Pendidikan Tinggi. 2006. Panduan Pelaksanaan Sistem Penjaminan Mutu Perguruan Tinggi. Direktorat Jenderal Pendidikan Tinggi. Kementerian Pendidikan Nasional. Jakarta.

Fikri, S., W.Wiyani, dan A.Suwandaru. 2016. Pengaruh Kualitas Pelayanan Terhadap Kepuasan dan Loyalitas Mahasiswa. Jurnal Bisnis dan Manajemen. Vol 3 No.1 Januari 2016.https://media.neliti.com

Halil, Tajidan, Mulyati, Rosmilawati. 2015. Evaluasi Proses Belajar Mengajar di Fakultas Pertanian Universitas Mataram. Fakultas Pertanian Universitas Mataram. Mataram.

Panjaitan, JE., 2016. Pengaruh Kualitas Pelayanan Terhadap Kepuasan Pelanggan Pada JNE Cabang Bandung. Jurnal Manajemen Volume 11 Nomor 2 November 2016. https://ojs.uph.edu.

Riadi, M. 2013. Kualitas Pelayanan Pelanggan. Kajian Pustaka. https://www.kajianpustaka.com.

Sari, Suci Wulan, 2015. Kepuasan Konsumen Terhadap Kualitas Pelayanan di Ndalem Ngabean Resto. https://eprints.uny.ac.id.

Suheri, H., Halil, M.Siddik, Rosmilawati, 2016. Evaluasi Penerapan Sistem Penjaminan Mutu Internal (SPMI) di Fakultas Pertanian Universitas Mataram. Fakultas Pertanian Universitas Mataram. Mataram.

Sukartono, Tajidan, Lestari Ujianto, Ahmad Zubaidi, dan Bustan, 2017. Kajian Audit Mutu Akademik Internal (AMAI): Suatu Pendekatan Analisis Risiko Penjaminan Mutu Berkelanjutan di Fakultas Pertanian Universitas Mataram. Lembaga Penelitian dan Pengabdian Universitas Mataram. Mataram

Tjiptono, F., 2016. Kualitas Pelayanan: Dimensi dan Cara Mengukurnya. https://www.ciputraoceo.net.

Tajidan, I Wayan Sutresna, Sukartono, Aris Budianto, Irwan Muthahanas, 2016. Studi Penelusuran (Tracer Study) Alumni Fakultas Pertanian Universitas Mataram Tahun Wisuda 2012-2015. Fakultas Pertanian Universitas Mataram. Mataram.

Wardani, Tri Ulfa, 2017. Pengaruh Kualitas Pelayanan Terhadap Kepuasan Konsumen Pada Bisnis Jasa Transportasi Go-Jek.repository.uinsu.ac.id 